\title{
Advancing Marine Biogeochemical and Ecosystem Reanalyses and Forecasts as Tools for Monitoring and Managing Ecosystem Health
}

\begin{abstract}
Katja Fennel ${ }^{1 *}$, Marion Gehlen ${ }^{2}$, Pierre Brasseur ${ }^{3}$, Christopher W. Brown ${ }^{4}$, Stefano Ciavatta ${ }^{5}$, Gianpiero Cossarini ${ }^{6}$, Alessandro Crise ${ }^{6}$, Christopher A. Edwards ${ }^{7}$, David Ford ${ }^{8}$, Marjorie A. M. Friedrichs ${ }^{9}$, Marilaure Gregoire ${ }^{10}$, Emlyn Jones ${ }^{11}$, Hae-Cheol Kim ${ }^{4,12}$, Julien Lamouroux ${ }^{13}$, Raghu Murtugudde ${ }^{14}$, Coralie Perruche ${ }^{13}$ and the GODAE OceanView Marine Ecosystem Analysis and Prediction Task Team
\end{abstract}

\section{OPEN ACCESS}

Edited by:

Sanae Chiba

Japan Agency for Marine-Earth Science and Technology, Japan

Reviewed by:

John Patrick Dunne,

Geophysical Fluid Dynamics Laboratory (GFDL), United States

Onur Kerimoglu,

Helmholtz Centre for Materials and Coastal Research (HZG),

Germany

${ }^{*}$ Correspondence: Katja Fennel katja.fennel@dal.ca

Specialty section: This article was submitted to Marine Biogeochemistry,

a section of the journal

Frontiers in Marine Science

Received: 31 October 2018 Accepted: 14 February 2019 Published: 13 March 2019

Citation:

Fennel K, Gehlen M, Brasseur P. Brown CW, Ciavatta S, Cossarini $G$,

Crise A, Edwards CA, Ford $D$

Friedrichs MAM, Gregoire M

Jones E, Kim H-C, Lamouroux J, Murtugudde $R$, Perruche $C$ and the

GODAE OceanView Marine Ecosystem Analysis and Prediction Task Team (2019) Advancing Marine

Biogeochemical and Ecosystem Reanalyses and Forecasts as Tools for Monitoring and Managing Ecosystem Health. Front. Mar. Sci. 6:89.

doi: 10.3389/fmars.2019.00089
1 Department of Oceanography, Dalhousie University, Halifax, NS, Canada, ${ }^{2}$ UMR8212 Laboratoire des Sciences du Climat et de l'Environnement (LSCE), Gif-sur-Yvette, France, ${ }^{3}$ Université Grenoble Alpes, CNRS, IRD, Grenoble INP, IGE, Grenoble, France, ${ }^{4}$ National Oceanic and Atmospheric Administration (NOAA), College Park, MD, United States, ${ }^{5}$ National Centre for Earth Observation, Plymouth Marine Laboratory, Plymouth, United Kingdom, ${ }^{6}$ Istituto Nazionale di Oceanografia e di Geofisica Sperimentale (OGS), Trieste, Italy, ${ }^{7}$ Ocean Sciences Department, University of California, Santa Cruz, Santa Cruz, CA, United States, ${ }^{8}$ Met Office, Exeter, United Kingdom, ${ }^{9}$ Virginia Institute of Marine Science, William \& Mary, Gloucester Point, VA, United States, ${ }^{10}$ MAST-FOCUS, Department of Astrophysics, Geophysics and Oceanography, Liége University, Liége, Belgium, ${ }^{11}$ Commonwealth Scientific and Industrial Research Organisation (CSIRO), Hobart, TAS, Australia, ${ }^{12}$ I.M. Systems Group, Inc., Rockville, MD, United States, ${ }^{13}$ Mercator Océan, Ramonville-Saint-Agne, France, ${ }^{14}$ Department of Atmospheric and Oceanic Science, University of Maryland, College Park, MD, United States

Ocean ecosystems are subject to a multitude of stressors, including changes in ocean physics and biogeochemistry, and direct anthropogenic influences. Implementation of protective and adaptive measures for ocean ecosystems requires a combination of ocean observations with analysis and prediction tools. These can guide assessments of the current state of ocean ecosystems, elucidate ongoing trends and shifts, and anticipate impacts of climate change and management policies. Analysis and prediction tools are defined here as ocean circulation models that are coupled to biogeochemical or ecological models. The range of potential applications for these systems is broad, ranging from reanalyses for the assessment of past and current states, and short-term and seasonal forecasts, to scenario simulations including climate change projections. The objectives of this article are to illustrate current capabilities with regard to the three types of applications, and to discuss the challenges and opportunities. Representative examples of global and regional systems are described with particular emphasis on those in operational or pre-operational use. With regard to the benefits and challenges, similar considerations apply to biogeochemical and ecological prediction systems as do to physical systems. However, at present there are at least two major differences: (1) biogeochemical observation streams are much sparser than physical streams presenting a significant hinderance, and (2) biogeochemical and ecological models are largely unconstrained because of insufficient observations. Expansion of biogeochemical and ecological observation systems will allow for significant advances in the development and application of analysis and prediction tools for ocean biogeochemistry and ecosystems, with multiple societal benefits.

Keywords: biogeochemical model, ecological model, forecasting, reanalysis, climate projection, scenario 


\section{INTRODUCTION}

Ocean warming, acidification, deoxygenation and eutrophication are manifesting on global (Bopp et al., 2013; Jickells et al., 2017; Schmidtko et al., 2017) and regional scales (Breitburg et al., 2018; Claret et al., 2018; Irby et al., 2018; Laurent et al., 2018; Fennel and Testa, 2019). These profound changes in ocean physics and biogeochemistry in combination with the ever more efficient harvesting of living marine resources are driving major shifts in marine ecosystems (Cheung et al., 2010; Bianucci et al., 2016; Brennan et al., 2016; Galbraith et al., 2017) with significant societal impacts. Changes in ocean biogeochemistry and ecosystems will also complicate conservation efforts for endangered species but are rarely considered in species recovery planning (e.g., Hartman et al., 2014). Strategies for mitigation, adaptation and protection, ranging from nutrient management in watersheds, fisheries management and Marine Protected Areas, to emission reductions of $\mathrm{CO}_{2}$ and other greenhouse gases, have to be designed, continuously assessed and revised. This process requires adequate observation of ongoing changes, combined with skillful analysis and prediction tools that provide decision makers and the public with the necessary information to assess the impact of policy decisions.

In this context, the term "analysis and prediction tool" refers to model systems that include realistic representations of ocean circulation coupled with biogeochemical or ecological models. The biogeochemical/ecological model components have a broad range of complexities from simple parameterizations, to fully explicit representations of multiple nutrients and functional groups and serve three major purposes: (1) hindcasts or reanalyses for assessment of past and current states and trends of the system, (2) forecasts ranging from short-term (days to weeks) to seasonal (months) time windows, and (3) scenario simulations including climate change projections and nutrient reduction scenarios. While operational systems are sometimes narrowly defined as only those providing short-term forecasts, we adopt a broader definition here that encompasses the provision of hindcasts and reanalyses, short-term/seasonal forecasts, and scenarios/projections.

Building on the recent review by Gehlen et al. (2015), this article focuses on the current state and future prospect of analysis and prediction tools for ocean biogeochemistry and ecosystems. While the necessity of a tight integration of these tools with observations cannot be overstated, we focus here on the tools themselves. Overviews of the necessary observing system components are given by Roemmich et al. (unpublished) and others in this issue.

\section{CURRENT STATUS}

With the goal of illustrating the current status and breadth of ecological/biogeochemical analysis and prediction systems we present a selective overview of global and regional systems. First, we briefly describe two global forecasting systems with biogeochemistry that operate in pre-operational or operational mode to produce short-term forecasts, reanalyses and climate projections (also see Gehlen et al., 2015). We then provide examples of regional analysis and prediction systems (also see Table 1). All produce estimates of the biogeochemical ocean state to benefit economic, environmental and public safety needs with users in academia, government, private companies and the general public.

\section{Global Applications NEMO-HadOCC and NEMO-MEDUSA}

The United Kingdom Met Office runs an operational global physical forecasting system referred to as FOAM (Blockley et al., 2014) which is based on the NEMO hydrodynamic model (Madec, 2008), and assimilates satellite and in situ data using the 3D-Var NEMOVAR scheme (Waters et al., 2015). FOAM is coupled pre-operationally to two biogeochemical components: HadOCC by Palmer and Totterdell (2001) and MEDUSA by Yool et al. (2013), for reanalyses and Ocean Observing System Simulation Experiments (OSSEs). NEMO-MEDUSA is also used for climate projections as part of the UKESM1 climate model (Kwiatkowski et al., 2014).

FOAM-HadOCC and FOAM-MEDUSA are assimilating satellite chlorophyll using 3D-Var to produce an update of surface $\log _{10}$ (chlorophyll), and then calculating multivariate increments for other biogeochemical variables using the balancing scheme of Hemmings et al. (2008). This computationally efficient way to perform multivariate updates has been applied for preoperational forecasting (Ford et al., 2012) and reanalysis (Ford and Barciela, 2017). A similar approach has also been used to assimilate in situ $\mathrm{pCO}_{2}$ observations into FOAM-HadOCC, by first calculating a surface $\mathrm{pCO}_{2}$ analysis, and then multivariate balances to DIC and alkalinity (While et al., 2012). Despite the sparse observations, the assimilation produces long-lasting corrections to the model.

FOAM-MEDUSA has the capability to assimilate profiles of chlorophyll, nitrate, oxygen, and $\mathrm{pH}$ using 3D-Var (Wood et al., 2018). OSSEs with this coupled system have shown the positive impacts of a BGC-Argo array (Johnson and Claustre, 2016) on model results (Wood et al., 2018).

\section{NEMO-PISCES}

Mercator Ocean operationally runs a global physical NEMO model for short-term forecasts and reanalyses. The biogeochemical model PISCES (Aumont et al., 2015) is operated offline in a coarsened $1 / 4^{\circ}$ version of the $1 / 12^{\circ}$ operational NEMO system (Lellouche et al., 2018) for weekly analyses and delivers daily/monthly means and 10-day forecasts.

Operational assimilation of satellite chlorophyll using a SEEK filter (Lellouche et al., 2013) is being implemented with the goal of constraining simulated large-scale structures including chlorophyll amplitudes, extension of oligotrophic gyres, and large-scale blooms. The multivariate scheme is able to provide surface corrections of simulated phytoplankton groups and nutrient concentrations, which are then projected vertically throughout the mixed layer.

NEMO-PISCES is also used for climate projections (Séférian et al., 2012; Bopp et al., 2013) contributing to IPCC assessments. In retrospective forecasts, the multi-year predictability of ocean 
TABLE 1 | Examples of analysis and prediction tools for ocean biogeochemistry and ecosystems.

\begin{tabular}{|c|c|c|c|c|c|c|c|}
\hline $\begin{array}{l}\text { Model acronym, } \\
\text { reference }\end{array}$ & Region ${ }^{1}$ & Mode $^{2}$ & $\begin{array}{l}\text { Product } \\
\text { class }^{3}\end{array}$ & $\begin{array}{l}\text { Type of DA } \\
\text { (if any) }\end{array}$ & Data used for DA & Data used validation & Link to products \\
\hline NEMO-PISCES ${ }^{a}$ & Global & $\mathrm{O}, \mathrm{PO}, \mathrm{RD}$ & $P, R, S$ & NA & $\begin{array}{l}\text { No assimilation of } \\
\text { biogeochemical data }\end{array}$ & $\begin{array}{l}\text { Ocean color; In situ } \\
\text { nutrients, chlorophyll, } \\
\text { oxygen, } \mathrm{pCO}_{2}, \mathrm{pH}\end{array}$ & marine.copernicus.eu \\
\hline NEMO-ERSEM ${ }^{b}$ & NWS & $\mathrm{O}, \mathrm{PO}$ & $\mathrm{P}, \mathrm{R}, \mathrm{S}$ & 3D-Var & $\begin{array}{l}\text { Ocean color total } \\
\text { chlorophyll and PFT } \\
\text { chlorophyll; DA for } \\
\text { spectral PFT } \\
\text { absorption and glider } \\
\text { and float data is under } \\
\text { development }\end{array}$ & $\begin{array}{l}\text { Ocean color; In situ } \\
\text { nutrients, chlorophyll, } \\
\text { oxygen, } \mathrm{fCO}_{2}, \mathrm{pH}\end{array}$ & marine.copernicus.eu \\
\hline $\begin{array}{l}\text { POLCOMS- } \\
\text { ERSEMC }^{C}\end{array}$ & NWS & $\mathrm{RD}$ & $\mathrm{R}$ & EnKF & $\begin{array}{l}\text { Ocean color: total } \\
\text { chlorophyll; PFT } \\
\text { chlorophyll; spectral } \\
\text { diffuse light attenuation } \\
\text { coefficient }\end{array}$ & $\begin{array}{l}\text { Ocean color; In situ } \\
\text { nutrients, chlorophyll, } \\
\text { oxygen, } \mathrm{fCO}_{2}, \mathrm{pH}\end{array}$ & $\begin{array}{l}\text { portal.ecosystem- } \\
\text { modelling.pml.ac.uk }\end{array}$ \\
\hline ROMS-NEMURO ${ }^{d}$ & CCS & $\mathrm{PO}, \mathrm{RD}$ & $P, R$ & 4D-Var & $\begin{array}{l}\text { Satellite chlorophyll, } \\
\text { physical data }\end{array}$ & $\begin{array}{l}\text { In situ chlorophyll, } \\
\text { nutrients, oxygen, rates }\end{array}$ & oceanmodeling.ucsc.edu \\
\hline eReefs $^{e}$ & GBR & $\mathrm{PO}, \mathrm{RD}$ & $\mathrm{R}$ & EnKF & Spectral ocean color & $\begin{array}{l}\text { Chlorophyll } \\
\text { fluorescence from } \\
\text { gliders, in situ nutrients }\end{array}$ & www.ereefs.info \\
\hline ROMS-ECB ${ }^{f}$ & $\mathrm{CB}$ & $\mathrm{PO}, \mathrm{RD}$ & $P, R$ & none & $\begin{array}{l}\text { No assimilation of } \\
\text { biogeochemical data }\end{array}$ & $\begin{array}{l}\text { Satellite chlorophyll, } \\
\text { in situ nutrients, oxygen }\end{array}$ & $\begin{array}{l}\text { www.vims.edu/hypoxia; } \\
\text { oceansmap.maracoos.org; } \\
\text { comt.ioos.us }\end{array}$ \\
\hline ROMS-DOg & GoMex & $\mathrm{PO}$ & $P$ & none & $\begin{array}{l}\text { No assimilation of } \\
\text { biogeochemical data }\end{array}$ & In situ oxygen & $\begin{array}{l}\text { pong.tamu.edu/ } \\
\text { tabswebsite }\end{array}$ \\
\hline ROMS-Fennel ${ }^{\text {h }}$ & GoMex & $\mathrm{RD}$ & $\mathrm{R}, \mathrm{S}$ & none & $\begin{array}{l}\text { No assimilation of } \\
\text { biogeochemical data }\end{array}$ & $\begin{array}{l}\text { Satellite chlorophyll, } \\
\text { in situ nutrients, } \\
\text { oxygen, rates, DIC, } \\
\text { alkalinity, } \mathrm{pCO}_{2}\end{array}$ & comt.ioos.us \\
\hline OGSTM-BFMi & Med & $\mathrm{O}$ & $\mathrm{R}, \mathrm{P}$ & 3D-Var & $\begin{array}{l}\text { Satellite chlorophyll; } \\
\text { BGC-Argo chlorophyll } \\
\text { and nitrate (in PO } \\
\text { mode); Physical data }\end{array}$ & $\begin{array}{l}\text { In situ chlorophyll, } \\
\text { nutrients ( } \mathrm{N} \text { and } \mathrm{P}) \text {, } \\
\text { oxygen, DIC and } \\
\text { Alkalinity }\end{array}$ & $\begin{array}{l}\text { marine.copernicus.eu; } \\
\text { medeaf.inogs.it/forecast }\end{array}$ \\
\hline MITgcm-BFMk & NAdr & $\mathrm{PO}, \mathrm{RD}$ & $\mathrm{P}$ & none & $\begin{array}{l}\text { No assimilation of } \\
\text { biogeochemical data }\end{array}$ & $\begin{array}{l}\text { In situ chlorophyll, } \\
\text { nutrients ( } \mathrm{N} \text { and } \mathrm{P}) \text { and } \\
\text { oxygen }\end{array}$ & medeaf.inogs.it/adriatic \\
\hline GHER-BAMHBIj & Black Sea & $\mathrm{O}$ & $\mathrm{R}, \mathrm{P}$ & SEEK filter & Argo oxygen & $\begin{array}{l}\text { Satellite chlorophyll, } \\
\text { Argo oxygen, in situ } \\
\text { nutrients }\end{array}$ & marine.copernicus.eu \\
\hline
\end{tabular}

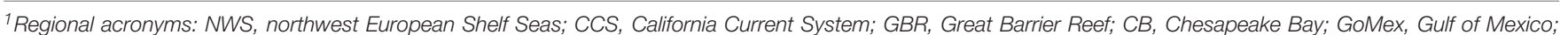

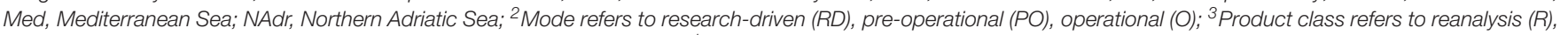
prediction (P), scenarios (S); ' Aumont et al., 2015; Lellouche et al., 2018; 'b Edwards et al., 2012; O'Dea et al., 2017; Skákala et al., 2018; 'C Ciavatta et al., 2014, 2016, 2018; ' Song et al., 2016a,b,c; Mattern et al., 2017; ' Baird et al., 2016, 2018; Jones et al., 2016; fFeng et al., 2015; Da et al., 2018; Irby et al., 2018; Irby and Friedrichs, 2019; g Hetland and DiMarco, 2008; Yu et al., 2015; ' 'Fennel et al., 2011; Laurent et al., 2012; 'Lazzari et al., 2016; Teruzzi et al., 2018; Cossarini et al., 2019; 'Grégoire et al., 2008; Capet et al., 2016; ' Cossarini et al., 2019.

productivity has been explored following decadal prediction protocols (Séférian et al., 2013). The model also has options to represent higher trophic levels of the marine food web allowing investigations of climate change impacts on the whole ecosystem (Lefort et al., 2014).

\section{Regional Applications Hindcasts and Short-Term Forecasts for the Northwest European Shelf Seas}

The Northwest European Shelf Seas (NWS) in the northeast North Atlantic Ocean hosts productive ecosystems of significant interest to several European nations. An operational prediction system for the NWS (Edwards et al., 2012; O'Dea et al., 2017) is maintained by the United Kingdom Met Office. It is based on NEMO (Madec, 2008), and includes a biogeochemical component based on ERSEM (Blackford et al., 2004; Butenschön et al., 2016). The operational forecasting system assimilates physical data using 3D-Var NEMOVAR (King et al., 2018) and provides daily analyses and 6-day forecasts of physical and biogeochemical variables. Assimilation of satellite chlorophyll is currently used for reanalyses and will be implemented for short-term forecasting in the near-future.

Besides total chlorophyll, the system can assimilate a regional ocean-color product for phytoplankton functional types (PFTs, Skákala et al., 2018), which has been shown to improve the plankton community structure 
and air-sea carbon fluxes in a multi-annual reanalysis (Ciavatta et al., 2018). Developments to allow direct assimilation of ocean color spectral data (Ciavatta et al., 2014) and assimilation of glider and float observations are ongoing.

\section{Reanalysis and Short-Term Forecasts for the Mediterranean Sea}

The semi-enclosed Mediterranean Sea is of significant importance to several European, Middle-East and African nations for fisheries, tourism, etc. Decadal reanalyses and short-term predictions for the Mediterranean are produced by an operational NEMO system (Tonani et al., 2014) that is coupled off-line with an assimilative biogeochemical system (Cossarini et al., 2015; Lazzari et al., 2016; Teruzzi et al., 2018). The system uses 3D-Var data for assimilation of physical fields (Dobricic and Pinardi, 2008) and satellite chlorophyll (Teruzzi et al., 2018).

Currently, assimilation of BGC-Argo data is in preoperational mode (Cossarini et al., 2019) and shows the positive impact of observed chlorophyll and nitrate profiles on simulated vertical phytoplankton distributions throughout the year. A decadal reanalysis with assimilation of physical variables and satellite chlorophyll has shown trends and anomalies in nutrients and air-sea $\mathrm{CO}_{2}$ fluxes in the Mediterranean (von Schuckmann et al., 2018).

\section{Hindcasts and Short-Term Forecasts for the California Current System}

The California Current System (CCS) is a productive upwelling region encompassing waters of the eastern Pacific off the US west coast. A data-assimilative physicalbiogeochemical forecast system for this region operates quasi-operationally at the University of California, Santa Cruz (Moore et al., 2013). The system uses ROMS (Shchepetkin and McWilliams, 2005; Haidvogel et al., 2008) with a horizontal resolution of $1 / 10^{\circ}$ (Veneziani et al., 2009) and meteorological forcing from COAMPS (Hodur et al., 2002). A 4D-Var method (Moore et al., 2011a,b) is applied to assimilate multiple remotely sensed and in situ physical data.

The biogeochemical component is based on NEMURO (Kishi et al., 2007; Fiechter et al., 2014) and constrained using a lognormal form of $4 \mathrm{D}$-Var (Song et al., 2012) to account for the non-Gaussian statistics of biogeochemical observations (see Song et al., 2016a,b,c; Mattern et al., 2017, for more details). Presently only satellite-derived chlorophyll is assimilated, because of its high temporal and spatial coverage.

The system has also been used to produce a 30year reanalysis (Broquet et al., 2009; Neveu et al., 2016) enabling analyses of regional climate variability (Jacox et al., 2014, 2015, 2016; Crawford et al., 2017) and the identification of habitats for marine fisheries (Schroeder et al., 2014, 2018; Scales et al., 2017) and marine mammals (Becker et al., 2016).

\section{Short-Term Forecasts for Australia's Great Barrier Reef System}

The Great Barrier Reef off northeast Australia is a world heritage site but under pressure from agricultural runoff, coral bleaching, crown of thorns starfish outbreaks, ocean warming and acidification, and mechanical damage from tropical cyclones. The eReefs biogeochemical modeling system (Baird et al., 2016) was developed to capture key processes related to water quality including carbonate chemistry (Mongin et al., 2016), bio-optics and bleaching (Baird et al., 2018).

The eReefs system uses a 100-member Ensemble Kalman Filter to assimilate ocean color spectral bands (Jones et al., 2016). The model predicts inherent and apparent optical properties through direct simulation of 17 optically active constituents at 8 spectral bands. This allows for prediction of remote sensing reflectances of the 8 MODIS ocean-color bands and avoids representation errors by directly simulating observed quantities. A reanalysis is available from June 2013 to October 2016. Relative to the assimilation of chlorophyll, forecast errors are reduced by up to $50 \%$, and representation of gliderderived fluorescence and in situ observations of nutrients, both withheld from assimilation, is improved by 45 and $20-$ $30 \%$, respectively.

\section{Reanalyses, Short-Term Forecasts and Scenarios for Chesapeake Bay}

Chesapeake Bay is a large, productive estuary in the United States that suffers from severe eutrophication and hypoxia. Realtime nowcasts and 2-day forecasts of temperature, salinity and oxygen are produced using the ROMS-based Estuarine, Carbon and Biogeochemistry (ECB) model (Feng et al., 2015; Da et al., 2018; Irby et al., 2018; Irby and Friedrichs, 2019). The forecast system, based in large part on earlier developments by NOAA and the University of Maryland (Brown et al., 2013), uses operationally available forcing from the North American Mesoscale Forecast System and USGS river fluxes. The system of Brown et al. (2013) also predicts the occurrence of several noxious species including jellyfish, harmful algal blooms and water-borne pathogens. While the biogeochemical variables are forecast mechanistically, the species predictions are generated using multivariate empirical habitat suitability models of the target species.

Input from stakeholder meetings has revealed that the ecological forecasts are useful to end-users whose lives and livelihoods depend on Chesapeake Bay, e.g., by guiding recreational and commercial fishermen to productive fishing grounds. The forecasts also inform the Annual Chesapeake Bay Hypoxia Report Card (https://www.vims.edu/research/topics/dead_zones/forecasts/ report_card/index.php) which helps managers and the public in assessing water-quality improvements of Chesapeake Bay.

The model has also been used for reanalysis studies quantifying the impact of atmospheric nitrogen deposition ( $\mathrm{Da}$ et al., 2018) and the uncertainties associated with hypoxia mitigation due to recent nutrient reductions (Irby and Friedrichs, 2019) and future climate change (Irby et al., 2018). 


\section{Short-Term Forecasts, Reanalyses and Scenarios of Hypoxia in the Northern Gulf of Mexico}

The northern Gulf of Mexico shelf receives large inputs of freshwater and anthropogenically derived nutrients leading to the formation of a large hypoxic zone every summer. A suite of models have been developed to improve understanding of the underlying mechanisms and for operational uses ranging from short-term and seasonal predictions, seasonal and multi-year hindcasts to scenario simulations and climate change projections.

A multi-model intercomparison (Fennel et al., 2016) indicated that a skillful physical model combined with a simple oxygen model (Hetland and DiMarco, 2008; Yu et al., 2015) is sufficient for short-term predictions in this system. A ROMSbased short-term prediction system for dissolved oxygen is run pre-operationally at Texas A\&M University ${ }^{1}$. Longer hindcast and scenario simulations use more comprehensive biogeochemical models. The physical-biogeochemical model of Fennel et al. (2011) and Laurent et al. (2012) has been used for multi-year hindcasts to inform fisheries management (Langseth et al., 2014), simulations of nutrient reduction scenarios (Fennel and Laurent, 2018), and future projections of hypoxia and $\mathrm{pH}$ conditions (Laurent et al., 2017, 2018). These inform the Hypoxia Taskforce, a multi-agency, multistate entity charged with devising strategies for reduction of the hypoxic zone and monitoring progress toward this goal (Task Force, 2001).

\section{POTENTIAL BENEFITS, CURRENT STATUS AND CHALLENGES}

Ocean biogeochemical and ecological analysis and prediction systems rely on skillful models of ocean physics. Thus, many of the same considerations that apply to operational systems for ocean physics do also apply for biogeochemical and ecological applications but there are important differences.

Potential benefits of biogeochemical/ecological operational systems include (1) the generation of dynamically and internally consistent reanalyses, nowcasts and forecasts through melding of observations with a dynamical model, (2) provision of oceanographic context for observations (from event scale to long-term trends and shifting baselines), (3) estimation of system properties that are not directly observable but can be inferred from dynamical models (e.g., biogeochemical fluxes), and (4) spatial and temporal coverage not attainable by direct observation.

Currently there are only a few operational forecasting systems (i.e., systems maintained by an operational agency with strict commitment to routinely provide forecasts) that assimilate biogeochemical variables and several preoperational systems (i.e., those run by academics or operational agencies as demonstrations but without commitments for continuous operation). Some will transition to operational

${ }^{1}$ http://pong.tamu.edu/tabswebsite/ mode in the near future (see Section "Current Status" and Table 1).

Two main challenges hinder the implementation of biogeochemical and ecological forecasting and analysis systems: data availability, and adequacy of data-assimilation methods. Obviously adequate biogeochemical and ecological observation streams are required in addition to physical ocean observations. Access to biogeochemical observations at meaningful spatial and temporal scales is still limited, especially when required in real-time or near-real time. Currently, the main biogeochemical data stream used in assimilation is satellite ocean color, but this measurement is limited to the surface ocean and provides an imperfect proxy of phytoplankton biomass that, by itself, is insufficient for constraining the multiple biogeochemically active pools in the euphotic zone. Efforts are being made to maximize the benefits of ocean color observations, e.g., by assimilating spectral bands (Baird et al., 2016, 2018; Jones et al., 2016) or satellite-derived PFTs (Xiao and Friedrichs, 2014a,b; Ciavatta et al., 2018; Skákala et al., 2018). The limited availability of observations is especially serious in coastal applications where altimetry and ocean color measurements are compromised by bathymetry and a variety of optical constituents.

Another major difference from physical ocean models is that established assimilation methods (see, e.g., Moore et al., 2019) cannot be applied to biogeochemical and ecological variables in a straightforward manner. Reasons for this include the non-Gaussian characteristics of biogeochemical observations, the strong non-linearity of biogeochemical models and the frequent lack of direct correspondence between convenient observables and model variables. Also, experience has shown that assimilation of physical observations in coupled models often does not improve but degrades the biogeochemical state. Methods for accommodating nonGaussian distributions are being developed (Song et al., 2012). The strong non-linearity can only be addressed by broadening the suite of observed biogeochemical variables. Although the biogeochemical assimilation schemes described above are multivariate, i.e., assimilation of one variable (e.g., chlorophyll) results in updates to other variables (e.g., nutrient concentrations), the adequacy of these updates hinges on the accuracy of biogeochemical models and is not well tested. Rigorous validation of biogeochemical models and tests of their predictive skill will require increased information content in available data streams. The degradation of biogeochemical fields during physical assimilation appears to arise at least partly when physical and biogeochemical variables are updated independently in violation of property-property relationships and can be substantially reduced by accounting for their correlation (Yu et al., 2018).

In principle, schemes are available for assimilating properties other than ocean color products and data types other than surface observations (e.g., from floats and gliders), but thus far they have mostly been used in OSSE-type twin experiments where synthetic observations are used (Wood et al., 2018; Yu et al., 2018). The 
true test of these methods has to await better availability of biogeochemical observations.

The prospect of a global BGC-Argo array (Johnson and Claustre, 2016) holds great promise for open ocean applications by expanding the suite of observed properties and extending observations from the surface ocean into its interior (Fujii et al., this issue) but requires careful calibration and verification. BGC-Argo observations will allow for a rigorous validation of biogeochemical models and will provide much better constraints on their dynamics and vertical structure as shown by Cossarini et al. (2019) in the Mediterranean Sea model.

New observations may also elucidate previously unrecognized shortcomings in the dynamical models and prompt modifications/refinements of model structure/formulations. Our best hope for reducing models' structural uncertainty and improving their robustness and predictive skill is model development guided by an expanded observing system in concert with process studies, application of theory, and synthesis of other available information. Data assimilation is best used to correct stochastic variability in state estimates produced by structurally sound models,

\section{REFERENCES}

Aumont, O., Ethé, C., Tagliabue, A., Bopp, L., and Gehlen, M. (2015). PISCES-v2: an ocean biogeochemical model for carbon and ecosystem studies. Geosci. Model Dev. 8, 2465-2513. doi: 10.5194/gmd-8-24 65-2015

Baird, M. E., Cherukuru, N., Jones, E., Margvelashvili, N., Mongin, M., Oubelkheir, K., et al. (2016). Remote-sensing reflectance and true colour produced by a coupled hydrodynamic, optical, sediment, biogeochemical model of the Great Barrier Reef, Australia: comparison with satellite data. Environ. Modell. Soft. 78, 79-96. doi: 10.1016/j.envsoft.2015.11.025

Baird, M. E., Mongin, M., Rizwi, F., Bay, L. K., Cantin, N. E., Soja-Woźniak, M., et al. (2018). A mechanistic model of coral bleaching due to temperaturemediated light-driven reactive oxygen build-up in zooxanthellae. Ecol. Modell. 386, 20-37. doi: 10.1016/j.ecolmodel.2018.07.013

Becker, E. A., Forney, K. A., Fiedler, P. C., Barlow, J., Chivers, S. J., Edwards, C. A., et al. (2016). Moving towards dynamic ocean management: How well do modeled ocean products predict species distributions? Remote Sens. 8:149. doi: $10.3390 /$ rs8020149

Bianucci, L., Fennel, K., Chabot, D., Shackell, N., and Lavoie, D. (2016). Ocean biogeochemical models as management tools: a case study for Atlantic wolffish and declining oxygen. ICES J. Mar. Sci. 73, 263-274. doi: 10.1093/icesjms/fsv220

Blackford, J. C., Allen, J. I., and Gilbert, F. J. (2004). Ecosystem dynamics at six contrasting sites: a generic modelling study. J. Mar. Syst. 52, 191-215. doi: 10.1016/j.jmarsys.2004.02.004

Blockley, E. W., Martin, M. J., McLaren, A. J., Ryan, A. G., Waters, J., and Lea, D. J. (2014). Recent development of the Met Office operational ocean forecasting system: an overview and assessment of the new Global FOAM forecasts. Geosci. Model Dev. 7, 2613-2638. doi: 10.5194/gmd-7-2613-2014

Bopp, L., Resplandy, L., Orr, J. C., Doney, S. C., Dunne, J. P., Gehlen, M., et al. (2013). Multiple stressors of ocean ecosystems in the 21st century: projections with CMIP5 models. Biogeosciences 10, 6225-6245. doi: 10.5194/bg-10-62252013

Breitburg, D., Levin, L. A., Oschlies, A., Grégoire, M., Chavez, F. P., Conley, D. J., et al. (2018). Declining oxygen in the global ocean and coastal waters. Science 359:eaam7240. doi: 10.1126/science.aam7240

Brennan, C. E., Blanchard, H., and Fennel, K. (2016). Putting temperature and oxygen thresholds of marine animals in context of environmental change: a regional perspective for the Scotian Shelf and Gulf of St. Lawrence. PLoS One 11:e0167411. doi: 10.1371/journal.pone.0167411 rather than trying to correct for biases or inappropriate model structures.

\section{CONCLUSION}

The potential benefits and scope of applications of biogeochemical/ecological analysis and prediction systems are broad. Presently, the availability of relevant observations is limited, which is a major impediment and explains why biogeochemical/ecological operational systems are still in their infancy compared to physical ocean forecasting. An expansion of ocean observing systems to include more biogeochemical/ecological parameters is crucial for expanded operational services and operational models can help in the design of expanding observing systems.

\section{AUTHOR CONTRIBUTIONS}

KF wrote the manuscript with contributions from all authors.

Broquet, G., Edwards, C. A., Moore, A. M., Powell, B. S., Veneziani, M., and Doyle, J. D. (2009). Application of 4D-Variational data assimilation to the California Current System. Dyn. Atmos. Oceans 48, 69-92. doi: 10.1016/j.dynatmoce.2009. 03.001

Brown, C. W., Hood, R. R., Long, W., Jacobs, J., Ramers, D. L., Wazniak, C., et al. (2013). Ecological forecasting in Chesapeake Bay: using a mechanisticempirical modeling approach. J. Mar. Syst. 125, 113-125. doi: 10.1016/j.jmarsys. 2012.12.007

Butenschön, M., Clark, J. R., Aldridge, J. N., Allen, J. I., Artioli, Y., Blackford, J. C., et al. (2016). ERSEM 15.06: a generic model for marine biogeochemistry and the ecosystem dynamics of the lower trophic levels. Geosci. Model Dev. 9, 1293-1339. doi: 10.5194/gmd-9-1293-2016

Capet, A., Meysman, F., Akoumianaki, I., Soetaert, K., and Grégoire, M. (2016). Integrating sediment biogeochemistry into 3D oceanic models: a study of benthic-pelagic coupling in the Black Sea. Ocean Modell. 101, 83-100. doi: 10.1016/j.ocemod.2016.03.006

Cheung, W. W. L., Lam, V. W. Y., Sarmiento, J. L., Kearney, K., Watson, R., Zeller, D., et al. (2010). Large-scale redistribution of maximum fisheries catch potential in the global ocean under climate change. Glob. Change Biol. 16, 24-35. doi: 10.1111/j.1365-2486.2009.0 1995.x

Ciavatta, S., Brewin, R. J. W., Skákala, J., Polimene, L., de Mora, L., Artioli, Y., et al. (2018). Assimilation of ocean-color plankton functional types to improve marine ecosystem simulations. J. Geophys. Res. Oceans 123, 834-854. doi: 10. 1002/2017JC013490

Ciavatta, S., Kay, S., Saux-Picart, S., Butenschön, M., and Allen, I. (2016). Decadal reanalysis of biogeochemical indicators and fluxes in the North West European shelf-sea ecosystem. J. Geophys. Res. Oceans 121, 1824-1845. doi: 10.1002/ 2015JC011496

Ciavatta, S., Torres, R., Martinez-Vicente, V., Smyth, T., Dall'Olmo, G., Polimene, L., et al. (2014). Assimilation of remotely-sensed optical properties to improve marine biogeochemistry modelling. Prog. Oceanogr. 127, 74-95. doi: $10.1016 /$ j.pocean.2014.06.002

Claret, M., Galbraith, E. D., Palter, J. B., Bianchi, D., Fennel, K., Gilbert, D., et al. (2018). Rapid coastal deoxygenation due to ocean circulation shift in the NW Atlantic. Nat. Clim. Change 8, 866-872. doi: 10.1038/s41558-018-0 263-1

Cossarini, G., Lazzari, P., and Solidoro, C. (2015). Spatiotemporal variability of alkalinity in the Mediterranean Sea. Biogeosciences 12, 1647-1658. doi: 10.5194/ bg-12-1647-2015 
Cossarini, G., Mariotti, L., Feudale, L., Mignot, A., Salon, S., Taillandier, V., et al. (2019). Towards operational 3D-Var assimilation of chlorophyll Biogeochemical-Argo float data into a biogeochemical model of the Mediterranean Sea. Ocean Modell. 133, 112-128. doi: 10.1016/j.ocemod.2018. 11.005

Crawford, W., Moore, A. M., Jacox, M. G., Fiechter, J., Neveu, E., and Edwards, C. A. (2017). A resonant response of the California Current circulation to forcing by low frequency climate variability. Deep Sea Res. II 151, 16-36. doi: 10.1016/j.dsr2.2017.07.016

Da, F., Friedrichs, M. A. M., and St-Laurent, P. (2018). Impacts of atmospheric nitrogen deposition and coastal nitrogen fluxes on oxygen concentrations in Chesapeake Bay. J. Geophys. Res. Oceans 123, 5004-5025. doi: 10.1029/ 2018JC014009

Dobricic, S., and Pinardi, N. (2008). An oceanographic three-dimensional variational data assimilation scheme. Ocean Modell. 22, 89-105. doi: 10.1016/ j.ocemod.2008.01.004

Edwards, K. P., Barciela, R., and Butenschön, M. (2012). Validation of the NEMO-ERSEM operational ecosystem model for the North West European Continental Shelf. Ocean Sci. 8, 983-1000. doi: 10.5194/os-8-983-2012

Feng, Y., Friedrichs, M. A. M., Wilkin, J., Tian, H., Yang, Q., Hofmann, E. E., et al. (2015). Chesapeake Bay nitrogen fluxes derived from a land-estuarine-ocean biogeochemical modeling system: model description, evaluation and nitrogen budgets. J. Geophys. Res. Biogeosci. 120, 1666-1695. doi: 10.1002/2015JG0 02931

Fennel, K., Hetland, R., Feng, Y., and DiMarco, S. (2011). A coupled physicalbiological model of the Northern Gulf of Mexico shelf: model description, validation and analysis of phytoplankton variability. Biogeosciences $8,1881-$ 1899. doi: $10.5194 /$ bg- $8-1881-2011$

Fennel, K., and Laurent, A. (2018). N and P as ultimate and proximate limiting nutrients in the northern Gulf of Mexico: implications for hypoxia reduction strategies. Biogeosciences 15, 3121-3131. doi: 10.5194/bg-15-3121-2018

Fennel, K., Laurent, A., Hetland, R., Justić, D., Ko, D. S., Lehrter, J., et al. (2016). Effects of model physics on hypoxia simulations for the northern Gulf of Mexico: a model inter-comparison. J. Geophys. Res. Oceans 121, 5731-5750. doi: 10.1002/2015JC011577

Fennel, K., and Testa, J. M. (2019). Biogeochemical controls on coastal hypoxia. Аnnu. Rev. Mar. Sci. 11, 105-130. doi: 10.1146/annurev-marine-010318095138

Fiechter, J., Curchitser, E. N., Edwards, C. A., Chai, F., Goebel, N. L., and Chavez, F. P. (2014). Air-sea CO2 fluxes in the California Current: impacts of model resolution and coastal topography. Glob. Biogeochem. Cycles 28, 371-385. doi: 10.1002/2013GB004683

Ford, D., and Barciela, R. (2017). Global marine biogeochemical reanalyses assimilating two different sets of merged ocean colour products. Remote Sens. Environ. 203, 40-54. doi: 10.1016/j.rse.2017.03.040

Ford, D. A., Edwards, K. P., Lea, D., Barciela, R. M., Martin, M. J., and Demaria, J. (2012). Assimilating GlobColour ocean colour data into a pre-operational physical-biogeochemical model. Ocean Science 8, 751-771. doi: 10.5194/os-8751-2012

Galbraith, E. D., Carozza, D. A., and Bianchi, D. (2017). A coupled humanEarth model perspective on long-term trends in the global marine fishery. Nat. Commun. 8:14884. doi: 10.1038/ncomms 14884

Gehlen, M., Barciela, R., Bertino, L., Brasseur, P., Butenschön, M., Chai, F., et al. (2015). Building the capacity for forecasting marine biogeochemistry and ecosystems: recent advances and future developments. J. Operat. Oceanogr. 8, s168-s187. doi: 10.1080/1755876X.2015.1022350

Grégoire, M., Raick, C., and Soetaert, K. (2008). Numerical modeling of the deep Black Sea ecosystem functioning during the late 80's (eutrophication phase). Prog. Oceanogr. 76, 286-333. doi: 10.1016/j.pocean.2008.01.002

Haidvogel, D. B., Arango, H., Budgell, W. P., Cornuelle, B. D., Curchitser, E., Di Lorenzo, E., et al. (2008). Ocean forecasting in terrain-following coordinates: formulation and skill assessment of the regional ocean modeling system. J. Comput. Phys. 227, 3595-3624. doi: 10.1016/j.jcp.2007. 06.016

Hartman, W., VanderZwaag, D. L., and Fennel, K. (2014). Recovery planning for pacific marine species at risk in the wake of climate change and ocean acidification: Canadian practice, future courses. J. Environ. Law Pract. 27, 23-56.
Hemmings, J. C. P., Barciela, R. M., and Bell, M. J. (2008). Ocean color data assimilation with material conservation for improving model estimates of air-sea CO2 flux. J. Mar. Res. 66, 87-126. doi: 10.1357/002224008784815739

Hetland, R., and DiMarco, S. (2008). How does the character of oxygen demand control the structure of hypoxia on the Texas-Louisiana continental shelf? J. Mar. Syst. 70, 49-62. doi: 10.1016/j.jmarsys.2007.03.002

Hodur, R. M., Pullen, J., Cummings, J., Hong, X., Doyle, J. D., Martin, P., et al. (2002). The Coupled Ocean/Atmosphere Mesoscale Prediction System (COAMPS). Oceanography 15, 88-98.

Irby, I. D., and Friedrichs, M. A. M. (2019). Evaluating confidence in the impact of regulatory nutrient reduction on Chesapeake Bay water quality. Estuar. Coasts 42, 16-32. doi: 10.1007/s12237-018-0440-5

Irby, I. D., Friedrichs, M. A. M., Da, F., and Hinson, K. (2018). The competing impacts of climate change and nutrient reductions on dissolved oxygen in Chesapeake Bay. Biogeosciences 15, 2649-2668. doi: 10.5194/bg-15-2649-2018

Jacox, M. G., Fiechter, J., Moore, A. M., and Edwards, C. A. (2015). ENSO and the California Current coastal upwelling response. J. Geophys. Res. Oceans 120, 1691-1702. doi: 10.1371/journal.pone.0125177

Jacox, M. G., Hazen, E. L., Zaba, K. D., Rudnick, D. L., Edwards, C. A., Moore, A. M., et al. (2016). Impacts of the 2015-2016 El Ninño on the California Current System: early assessment and comparison to past events. Geophys. Res. Lett. 43, 7072-7080. doi: 10.1002/2016GL069716

Jacox, M. G., Moore, A. M., Edwards, C. A., and Fiechter, J. (2014). Spatially resolved upwelling in the California Current System and its connections to climate variability. Geophys. Res. Lett. 41, 3189-3196. doi: 10.1002/ 2014GL059589

Jickells, T. D., Buitenhuis, E., Altieri, K., Baker, A. R., Capone, D., Duce, R. A., et al. (2017). A reevaluation of the magnitude and impacts of anthropogenic atmospheric nitrogen inputs on the ocean. Glob. Biogeochem. Cycles 31, 289-305. doi: 10.1002/2016GB005586

Johnson, K., and Claustre, H. (2016). The scientific rationale, design, and implementation plan for a Biogeochemical-Argo float array. Biogeochem. Argo Plann. Group 58:65. doi: 10.13155/46601

Jones, E. M., Baird, M. E., Mongin, M., Parslow, J., Skerratt, J., Lovell, J., et al. (2016). Use of remote-sensing reflectance to constrain a data assimilating marine biogeochemical model of the Great Barrier Reef. Biogeosciences 13, 6441-6469. doi: 10.5194/bg-13-6441-2016

King, R. R., While, J., Martin, M. J., Lea, D. J., Lemieux-Dudon, B., Waters, J., et al. (2018). Improving the initialisation of the Met Office operational shelf-seas model. Ocean Modell. 130, 1-14. doi: 10.1016/j.ocemod.2018.07.004

Kishi, M. J., Kashiwai, M., Ware, D. M., Megrey, B. A., Eslinger, D. L., and Werner, F. E. (2007). NEMUROA lower trophic level model for the north pacific marine ecosystem. Ecol. Modell. 202, 12-25. doi: 10.1016/j.ecolmodel.2006. 08.021

Kwiatkowski, L., Yool, A., Allen, J. I., Anderson, T. R., Barciela, R., Buitenhuis, E. T., et al. (2014). iMarNet: an ocean biogeochemistry model intercomparison project within a common physical ocean modelling framework. Biogeosciences 11, 7291-7304. doi: 10.5194/bg-11-7291-2014

Langseth, B. J., Purcell, K. M., Craig, J. K., Schueller, A. M., Smith, J. W., Shertzer, K. W., et al. (2014). Effect of changes in dissolved oxygen concentrations on the spatial dynamics of the Gulf Menhaden fishery in the northern Gulf of Mexico. Mar. Coast. Fish. 6, 223-234. doi: 10.1080/19425120.2014.949017

Laurent, A., Fennel, K., Cai, W.-J., Huang, W.-J., Barbero, L., and Wanninkhof, R. (2017). Eutrophication-induced acidification of coastal waters in the northern Gulf of Mexico: results from a coupled physical-biogeochemical model. Geophys. Res. Lett. 44, 946-956. doi: 10.1002/2016GL071881

Laurent, A., Fennel, K., Hu, J., and Hetland, R. (2012). Simulating the effects of phosphorus limitation in the Mississippi and Atchafalaya river plumes. Biogeosciences 9, 4707-4723. doi: 10.5194/bg-9-4707-2012

Laurent, A., Fennel, K., Ko, D. S., and Lehrter, J. (2018). Climate change projected to exacerbate impacts of coastal eutrophication in the northern Gulf of Mexico. J. Geophys. Res. Oceans 123, 3408-3426. doi: 10.1002/2017JC 013583

Lazzari, P., Solidoro, C., Salon, S., and Bolzon, G. (2016). Spatial variability of phosphate and nitrate in the Mediterranean Sea: a modeling approach. Deep Sea Res. I 108, 39-52. doi: 10.1016/j.dsr.2015.12.006

Lefort, S., Aumont, O., Bopp, L., Arsouze, T., Gehlen, M., and Maury, M. O. (2014). Spatial and body-size dependent response of marine pelagic communities to 
projected global climate change. Glob. Change Biol. 21, 154-164. doi: 10.1111/ gcb. 12679

Lellouche, J.-M., Greiner, E., Le Galloudec, O., Garric, G., Regnier, C., Drevillon, M., et al. (2018). Recent updates to the Copernicus Marine Service global ocean monitoring and forecasting real-time $1 / 12^{\circ}$ high-resolution system. Ocean Sci. 14, 1093-1126. doi: 10.5194/os-14-1093-2018

Lellouche, J. M., Le Galloudec, O., Drévillon, M., Régnier, C., Greiner, E., Garric, G., et al. (2013). Evaluation of global monitoring and forecasting systems at Mercator Océan. Ocean Sci. 9, 57-81. doi: 10.5194/os-9-57-2013

Madec, G. (2008). NEMO ocean engine. Note du Pôle de modélisation, Institut Pierre-Simon Laplace (IPSL), France. Available at: https://www.nemo-ocean.eu/ wp-content/uploads/NEMO_book.pdf

Mattern, J. P., Song, H., Edwards, C. A., Moore, A. M., and Fiechter, J. (2017). Data assimilation of physical and chlorophyll observations in the California Current System using two biogeochemical models. Ocean Modell. 109, 55-71. doi: 10.1016/j.ocemod.2016.12.002

Mongin, M., Baird, M. E., Tilbrook, B., Matear, R. J., Lenton, A., Herzfeld, M., et al. (2016). The exposure of the Great Barrier Reef to ocean acidification. Nat. Commun. 7:10732. doi: 10.1038/ncomms10732

Moore, A., Edwards, C. A., Fiechter, J., Drake, P., Arango, H., Neveu, E., et al. (2013). "A 4D-Var Analysis System for the California Current: a prototype for an operational regional ocean data assimilation system," in Data Assimilation for Atmospheric, Oceanic and Hydrological Applications, Vol. II, eds L. Xu and S. Park (Berlin: Springer), 345-366. doi: 10.1007/978-3-642-35088-7_14

Moore, A. M., Arango, H. G., Broquet, G., Edwards, C. A., Veneziani, M., Powell, B. S., et al. (2011a). The Regional Ocean Modeling System (ROMS) 4-dimensional variational data assimilation systems. II: performance and application to the California current system. Prog. Oceanogr. 91, 50-73. doi: 10.1016/j.pocean.2011.05.003

Moore, A. M., Arango, H. G., Broquet, G., Powell, B. S., Zavala-Garay, J., and Weaver, A. T. (2011b). The regional ocean modeling system (ROMS) 4dimensional variational data assimilation systems. I: system overview and formulation. Prog. Oceanogr. 91, 34-49. doi: 10.1016/j.pocean.2011.05.004

Moore, A. M., Martin, M., Akella, S., Arango, H., Balmaseda, M. A., Bertino, L., et al. (2019). Synthesis of ocean observations using data assimilation: a more complete picture of the state of the ocean. Front. Mar. Sci. doi: 10.3389/fmars. 2019.00090

Neveu, E., Moore, A. M., Edwards, C. A., Fiechter, J., Drake, P. T., Jacox, M. G., et al. (2016). A historical analysis of the California Current using ROMS 4DVar. Part I: system configuration and diagnostics. Ocean Modell. 99, 133-151. doi: 10.1016/j.ocemod.2015.11.012

O’Dea, E., Furner, R., Wakelin, S., Siddorn, J., While, J., Sykes, P., et al. (2017). The CO5 configuration of the $7 \mathrm{~km}$ Atlantic Margin Model: large-scale biases and sensitivity to forcing, physics options and vertical resolution. Geosci. Model Dev. 10, 2947-2969. doi: 10.5194/gmd-10-2947-2017

Palmer, J. R., and Totterdell, I. J. (2001). Production and export in a global ocean ecosystem model. Deep Sea Res. I 48, 1169-1198. doi: 10.1016/S0967-0637(00) 00080-7

Scales, K., Hazen, E., Maxwell, S., Dewar, H., Kohin, S., Jacox, M., et al. (2017). Fit to predict? Ecoinformatics for modeling dynamic habitat suitability for highly migratory marine species. Ecol. Appl. 27, 2313-2329. doi: 10.1002/ eap. 1610

Schmidtko, S., Stramma, L., and Visbeck, M. (2017). Decline in global oceanic oxygen content during the past five decades. Nature 542, 335-339. doi: 10.1038/ nature21399

Schroeder, I. D., Santora, J. A., Bograd, S. J., Hazen, E. L., Sakuma, K. M., and Moore, A. M. (2018). Source water variability as a driver of rockfish recruitment in the California Current ecosystem. Can. J. Fish. Aquat. Sci. doi: 10.1139/cjfas2017-0480

Schroeder, I. D., Santora, J. A., Moore, A. M., Edwards, C. A., Fiechter, J., Hazen, E., et al. (2014). Application of a data-assimilative regional ocean modeling system for assessing California Current System ocean conditions, krill, and juvenile rockfish interannual variability. Geophys. Res. Lett. 41, 5942-5950. doi: 10.1002/ 2014GL061045

Séférian, R., Bopp, L., Gehlen, M., Orr, J., Éthé, C., Cadule, P., et al. (2012). Skill assessment of three earth system models with common marine biogeochemistry. Clim. Dyn. 40, 2549-2573. doi: 10.1007/s00382-012-1362-8
Séférian, R., Bopp, L., Gehlen, M., Swingedouw, D., Mignot, J., Guilyardi, E., et al. (2013). Multi-year prediction of tropical pacific marine productivity. Proc. Natl. Acad. Sci. U.S.A. 111, 11646-11651. doi: 10.1073/pnas.1315855111

Shchepetkin, A. F., and McWilliams, J. C. (2005). The regional oceanic modeling system (ROMS): a split-explicit, free-surface, topography-following-coordinate oceanic model. Ocean Modell. 9, 347-404. doi: 10.1016/j.ocemod.2004. 08.002

Skákala, J., Ford, D. A., Brewin, R. J., McEwan, R., Kay, S., Taylor, B. H., et al. (2018). The assimilation of phytoplankton functional types for operational forecasting in the North-West European Shelf. J. Geophys. Res. Oceans 123, 5230-5247. doi: 10.1029/2018JC014153

Song, H., Edwards, C. A., Moore, A. M., and Fiechter, J. (2012). Incremental fourdimensional variational data assimilation of positive-definite oceanic variables using a logarithm transformation. Ocean Modell. 5, 1-17. doi: 10.1016/j. ocemod.2012.06.001

Song, H., Edwards, C. A., Moore, A. M., and Fiechter, J. (2016a). Data assimilation in a coupled physical-biogeochemical model of the California Current System using an incremental lognormal 4-dimensional variational approach: part 1Model formulation and biological data assimilation twin experiments. Ocean Modell. 106, 131-145. doi: 10.1016/j.ocemod.2016.04.001

Song, H., Edwards, C. A., Moore, A. M., and Fiechter, J. (2016b). Data assimilation in a coupled physical-biogeochemical model of the California Current System using an incremental lognormal 4-dimensional variational approach: part 2Joint physical and biological data assimilation twin experiments. Ocean Modell. 106, 146-158. doi: 10.1016/j.ocemod.2016.09.003

Song, H., Edwards, C. A., Moore, A. M., and Fiechter, J. (2016c). Data assimilation in a coupled physical-biogeochemical model of the California current system using an incremental lognormal 4-dimensional variational approach: part 3 Assimilation in a realistic context using satellite and in situ observations. Ocean Modell. 106, 159-172. doi: 10.1016/j.ocemod.2016.06.005

Task Force (2001). Action Plan for reducing, mitigating, and controlling Hypoxia in the Northern Gulf of Mexico; Mississippi River/Gulf of Mexico Watershed Nutrient Task Force, Tech. Rep. Washington, DC: US Environmental Protection Agency.

Teruzzi, A., Bolzon, G., Salon, S., Lazzari, P., Solidoro, C., and Cossarini, G. (2018). Assimilation of coastal and open sea biogeochemical data to improve phytoplankton simulation in the Mediterranean Sea. Ocean Modell. 132, 46-60. doi: 10.1016/j.ocemod.2018.09.007

Tonani, M., Teruzzi, A., Korres, G., Pinardi, N., Crise, A., Adani, M., et al. (2014). "The Mediterranean monitoring and forecasting centre, a component of the MyOcean system," in Proceedings of the Sixth International Conference on EuroGOOS 4-6 October 2011, eds H. Dahlin, N. C. Fleming, and S. E. Petersson (Sopot: Eurogoos Publication).

Veneziani, M., Edwards, C. A., Doyle, J. D., and Foley, D. (2009). A central California coastal ocean modeling study: 1 . Forward model and the influence of realistic versus climatological forcing. J. Geophys. Res. Oceans 114:C0 4015.

von Schuckmann, K., Le Traon, P.-Y., Smith, N., Pascual, A., Brasseur, P., Fennel, K., et al. (2018). Copernicus marine service ocean state report. J. Oper. Oceanogr. 11, S1-S142. doi: 10.1080/1755876X.2018.1489208

Waters, J., Lea, D. J., Martin, M. J., Mirouze, I., Weaver, A., and While, J. (2015). Implementing a variational data assimilation system in an operational $1 / 4$ degree global ocean model. Q. J. R. Meteorol. Soc. 141, 333-349. doi: 10.1002/qj. 2388

While, J., Totterdell, I., and Martin, M. (2012). Assimilation of pCO2 data into a global coupled physical-biogeochemical ocean model. J. Geophys. Res. Oceans 117:C03037.

Wood, R., Ford, D., Gasprin, F., Palmer, M., Rémy, E., and Yves le Traon, P. (2018). Observing System Simulation Experiments (OSSEs): Report Describing the Robust Results Obtained from Across the Models. AtlantOS deliverable 1.5.

Xiao, Y., and Friedrichs, M. A. M. (2014a). The assimilation of satellitederived data into a one-dimensional lower trophic level marine ecosystem model. J. Geophys. Res. Oceans 119, 2691-2712. doi: 10.1002/2013JC00 9433

Xiao, Y., and Friedrichs, M. A. M. (2014b). Using biogeochemical data assimilation to assess the relative skill of multiple ecosystem models in the Mid-Atlantic Bight: effects of increasing the complexity of the 
planktonic food web. Biogeosciences 11, 3015-3030. doi: 10.5194/bg-11-30152014

Yool, A., Popova, E. E., and Anderson, T. R. (2013). MEDUSA-2.0: An intermediate complexity biogeochemical model of the marine carbon cycle for climate change and ocean acidification studies. Geosci. Model Dev. 6, 1767-1811. doi: 10.5194/gmd-6-1767-2013

Yu, L., Fennel, K., Bertino, L., Gharamti, M. E., and Thompson, K. R. (2018). Insights on multivariate updates of physical and biogeochemical ocean variables using an Ensemble Kalman Filter and an idealized model of upwelling. Ocean Modell. 126, 13-28. doi: 10.1016/j.ocemod.2018.04.005

Yu, L., Fennel, K., and Laurent, A. (2015). A modeling study of physical controls on hypoxia generation in the northern Gulf of Mexico. J. Geophys. Res. Oceans 120, 5019-5039. doi: 10.1002/2014JC010634
Conflict of Interest Statement: The authors declare that the research was conducted in the absence of any commercial or financial relationships that could be construed as a potential conflict of interest.

Copyright (๔ 2019 Fennel, Gehlen, Brasseur, Brown, Ciavatta, Cossarini, Crise, Edwards, Ford, Friedrichs, Gregoire, Jones, Kim, Lamouroux, Murtugudde, Perruche and the GODAE OceanView Marine Ecosystem Analysis and Prediction Task Team. This is an open-access article distributed under the terms of the Creative Commons Attribution License (CC BY). The use, distribution or reproduction in other forums is permitted, provided the original author(s) and the copyright owner(s) are credited and that the original publication in this journal is cited, in accordance with accepted academic practice. No use, distribution or reproduction is permitted which does not comply with these terms. 